\title{
QUALITY TRAIT SIGNATURE AT ARCHIPELAGO SCALE OF THE CULTURED PEARLS PRODUCED BY THE BLACK-LIPPED PEARL OYSTER (PINCTADA MARGARITIFERA VAR. CUMINGI) IN FRENCH POLYNESIA
}

\author{
CHIN-LONG KY, ${ }^{1 *}$ RETSU OKURA, ${ }^{2}$ SEIJI NAKASAI ${ }^{3}$ AND DOMINIQUE DEVAUX ${ }^{2,3}$ \\ ${ }^{1}$ Ifremer, UMR 241, EIO, Labex Corail, Centre du Pacifique, BP 7004, 98719 Taravao, Tahiti, Polynésie \\ Française; ${ }^{2}$ Groupement d'Intérêt Economique Poe O Rikitea, BP 176, 98755 Rikitea, Gambier, Polynésie \\ Française; ${ }^{3}$ SCA Regahiga Pearls, BP 48, 98755 Rikitea, Gambier, Polynésie Française
}

\begin{abstract}
In French Polynesia, the aquaculture of Pinctada margaritifera (Linnaeus, 1758) covers a large maritime exploitation area, spread over nearly 20 degrees latitude and longitude, with numerous pearl farms located in three archipelagos (Gambier, Society, and Tuamotu). As these archipelagos have specific seasonal temperature patterns each year, pearl oysters are subject to disparate and contrasting environmental regimes. This study aimed to examine the specificity of commercial pearl quality traits ( $n=2,236$ samples) at the archipelago scale, in such a way as to provide preliminary data to design the most appropriate strategy for the distribution of hatchery-produced phenotypes. A large and standardized grafting experiment using the same donor phenotype was designed and carried out over six grow-out locations, covering the three archipelagos. Results revealed significant differences in commercial pearl quality traits among archipelagos, giving these groups of growing sites distinctive "signatures": (1) more color, less circles, and higher overall pearl grade in Gambier; (2) larger size with paler pearls in Tuamotu; and (3) darker pearls with intermediate size in Society. Characteristic differences in the environment and seasonal temperature ranges among the three archipelagos, corresponding to their distinct environmental conditions, can explain the specific variations between pearl quality traits among the sites. The strong disparities at archipelago scale should be taken into account in selective breeding programs for $P$. margaritifera so as to choose the most appropriate pearl oyster donor phenotype for use in each environment and thus enhance site-specific qualities for pearl production.
\end{abstract}

KEY WORDS: pearl oyster, Pinctada margaritifera, large-scale geographic effects, pearl color, pearl grade, pearl shape, pearl size

\section{INTRODUCTION}

The cultured pearl is one of the most important and lucrative gems in the world. Part of this industry is based on beaded cultured pearls from species of the Pinctada genus species, including Akoya (Pinctada fucata), South Sea (Pinctada maxima), and Tahiti (Pinctada margaritifera) pearls. These pearls are grown in the oyster gonad, with usually only one pearl grown at a time per oyster. The corresponding grafting or seeding operation requires two elements, which are implanted into the gonad of a recipient pearl oyster: (1) a living tissue fragment (Saibo) from the mantle of a donor pearl oyster, along with (2) a small inorganic bead or "nucleus" (generally obtained from the shell of freshwater mussels from the Mississippi) (Taylor \& Strack 2008). Pearl production in French Polynesia is based on the aquaculture of the black-lipped pearl oyster $P$. margaritifera. This marine mollusc is found throughout the Indo-Pacific area and is particularly abundant in the lagoons of French Polynesia, where the cumingi variety is found (Le Pennec \& Buestel 2010). In this region, the black pearl industry remains the second most important economic activity, after tourism, and is the largest export industry ( 7.8 billion CFP francs in 2013). Statistics from 2013 showed that this industry had developed on 25 islands and atolls, covering nearly 7,800 ha of maritime surface area, with 517 recorded pearl farms located in three archipelagos: Tuamotu (398 farms), Gambier (79 farms), and Society (40 farms) (Talvard 2015).

Cultured pearl quality is defined according to a wide range of criteria, in which pearl classification grade, shape, color, and size are all determinants of value. Tahitian classification grading

*Corresponding author. E-mail: chinky@ifremer.fr DOI: $10.2983 / 035.035 .0410$
(Tayale et al. 2012) is further based on two components: pearl surface quality and lustre. Grade evaluation is made by a professional expert, without any magnification device such as a jeweler loupe. The five grade classes are A, B, C, D, and R (R graded pearls are rejects that cannot be exported from Tahiti). Shape is one of the principle determining factors of a cultured pearl value; the rounder a pearl is, the greater its value. Circled pearls generally account for $25 \%-30 \%$ of the cultured pearl harvest in Pinctada margaritifera. These cultured pearls develop concentric rings or grooves visible on the surface. Another remarkable specificity of this pearl oyster species is its ability to produce a wide range of pearl colors, determined by organic (pigments) and physical (reflectance) components (Karampelas et al. 2011). The size of $P$. margaritifera cultured pearls typically ranges from 8.0 to $20 \mathrm{~mm}$ in diameter and also determines value; with larger pearls (usually issued from a surgreffe operation, which consist of inserting a new nucleus in place of the harvested pearls, with no need for further saibo, into the same recipient) generally commanding higher prices (Matlins 1996, Strack 2006). According to Tahitian government regulations, all exported pearls must be screened by X-ray technology to ensure that their nacre thickness is at least $0.8 \mathrm{~mm}$. Cultured pearls with thinner nacre are rejected. It is estimated that only $5 \%$ of harvested pearls can be classed as grade A quality according to the local regulatory standards (Ellis \& Haws 1999).

The influence of the culture zone where the recipient oyster is reared on the quality of the end product is particularly important in French Polynesia; a territory that covers an area as large as Europe. French Polynesia includes 118 islands covering five archipelagos: Austral, Gambier, Marquesas, Tuamotu, and Society. These islands are very isolated in the South Pacific, between latitudes $7^{\circ} 50^{\prime} \mathrm{S}$ (Motu One sand bank) and $27^{\circ} 36^{\prime} \mathrm{S}$ (Marotiri rocks), and longitudes $154^{\circ} 40^{\prime} \mathrm{W}$ (Scilly Island) and 
$134^{\circ} 28^{\prime} \mathrm{W}$ (Temoe atoll). Many pearl farms and grow-out sites are geographically distant and subject to disparate environmental regimes. Few recent studies on Pinctada margaritifera have been set up to compare the impact of the environment on pearl quality realization at a macro-geographical scale. The first case study in French Polynesia compared Tahaa Island (Society) and Rangiroa atoll (Tuamotu) (Ky et al. 2015a). Overall intersite comparison revealed that (1) a higher mean percentage of valuable pearls was produced in Rangiroa and (2) for color variation, $10 \%$ more pearls have an attractive green overtone in Rangiroa than in Tahaa, where more pearls with gray bodycolor were harvested. More recently, Ky et al. (2015b) found that the color of pearls could be predicted from the combination of donor oyster phenotype and rearing environment. Such relations were also demonstrated in a study on Pinctada maxima in Indonesia by Jerry et al. (2012), which reported significant interactions for cultured pearl size, color, weight, shape, and lustre at two commercial grow-out locations (Bali and Lombok). Knowledge of the main tendencies and specificities of each culture zone would make it possible to orientate pearl production toward a particular trait or traits of interest. This is particularly true in the context of a breeding program for pearl quality traits, where an understanding of the interactions between animals and environment is essential to ensure maximum genetic gains (Wada \& Jerry 2008).

The aim of the study was, to evaluate the possible existence of macro-geographic specificity at the scale of different French Polynesian archipelagos, which have distinct and specific environments, for cultured pearl commercial quality traits in Pinctada margaritifera, namely shape, grade, color, and size. Understanding the strength and direction of these specific environmental influences will help us to understand their importance relative to the genetic/phenotypic contribution from the donor oyster. This will help future breeding programs, which are likely to involve the diffusion of genetically improved oyster lines and the rearing of oysters in geographically disparate locations. To conduct the study, a graft experiment was designed, in which the grafting process was kept as uniform as possible by using the same expert grafter, nucleus size and method (following the usual protocol as for commercial grafting), hatchery-produced donor oysters (same phenotype), and recipient oyster origin. To look for archipelago-specific effects, two grow-out sites were selected per archipelago: Gambier (Atiaoa and Taku bays), Society (Tahaa and Raiatea Islands), and Tuamotu (Ahe and Arutua atolls).

\section{MATERIALS AND METHODS}

\section{Experimental Animals}

First-generation hatchery-produced Pinctada margaritifera were used as donor oysters. This oyster family was issued from a multiparental cross using highly colored broodstock carried out at the Regahiga Pearl Farm and Hatchery company, located in Mangareva Island (Gambier archipelago, French Polynesia). Broodstock breeding, larval rearing, and culture of this family were done as described in Ky et al. (2015c). At the age of 20 months post-hatching, the donor pearl oysters were randomly selected from a set of healthy animals that showed "yellow" inner shell coloration. To discern the inner shell color for this set, the grafter used a speculum to gently pry open the oyster valves.
Wild Pinctada margaritifera were collected as spat in the lagoon of Mangareva Island (Gambier Archipelago, French Polynesia) to serve as recipients. Passive techniques were used for catching spat using commercial collectors, as described in Ky et al. (2014a). After nearly 1 y of subsurface rearing (3-5 m below the surface), the young pearl oysters ( $4-5 \mathrm{~cm}$ in diameter) were then removed from the collectors on which they had developed. These juveniles were pierced and tied together onto a Cord Technical Nakasai rearing system, where they were left until grafting. It involves drilling a small hole through the base of the shell in the dorsal-posterior region. This process doesnot affect living tissue. Mature oysters aged almost 20 months, measuring at least $7 \mathrm{~cm}$ in length, were taken from the Cord Technical Nakasai, detached, and stored ready to be used in the grafting procedure.

\section{Grafting Procedure and Experimental Design}

The grafting operation was conducted by an expert from the Regahiga Pearl Farm and Hatchery as described in Ky et al. (2015d). The nuclei used for this purpose were made from the shells of freshwater mussels (1.8 BU size, equivalent to $5.45 \mathrm{~mm}$ diameter, $0.26 \mathrm{~g}$ weight; Imai Seikaku Co. Ltd., Japan). The thickness and hardness of the nacreous layers of these beads show specific gravity and thermal conductivity that make them particularly suitable for use as nuclei (Gervis \& Sims 1992). The epithelial cells required for grafting were excised from the mantle of the selected donor pearl oysters $(n=144)$. A total of 2,880 grafts were performed ( 20 grafts per donor) over 5 days. All the grafted oysters were checked for nucleus retention/ rejection and mortality 45 days after the grafting operation, as described in Ky et al. (2014a). The oysters that had retained their nuclei were drilled and fixed onto chaplets (in the chaplets, oysters were attached in pairs to a rope with a monofilament fishing line), which constituted the rearing system (Ky et al. 2015a).

The graft operation took place in September 2012 in Gambier, and dispatch to the different grow-out sites was made 3 months later, during the main natural spawning season throughout French Polynesia. The recipient oysters grafted from the same donor oyster (grouped on chaplets) were then randomly split into six groups; two of these were kept in Gambier archipelago (Atiaoa and Taku bays), two others were taken to Tuamotu archipelago (atoll lagoons of Ahe and Arutua), and the last two to Society archipelago (lagoons of Raiatea and Tahaa Islands) (Fig. 1). All the oysters on chaplets were put in cooled iceboxes (without water) for $8 \mathrm{~h}$. This standardized duration has permitted to transfer the oysters to the different locations from Atiaoa Bay site where the grafts took place.Furthermore, pearl oysters were regularly cleaned in both sites, during the same periods and at the same frequency to remove biofouling (epibiota), which can hinder healthy oyster growth and pearl production.

\section{Measurement of Cultured Pearl Commercial Quality Traits}

After approximately 20 months, the cultured pearls were harvested. The pearls were cleaned by ultrasonication in soapy water (hand washing) with a LEO 801 laboratory cleaner (2-1 capacity, $80 \mathrm{~W}, 46 \mathrm{kHz}$ ); they were then rinsed in distilled water.

Shape and color were evaluated for all pearls by the same professional expert from the Poe $\mathrm{O}$ Rikitea association, according to the Tahitian pearl auction classification categories (Figs. 2 and 3). 


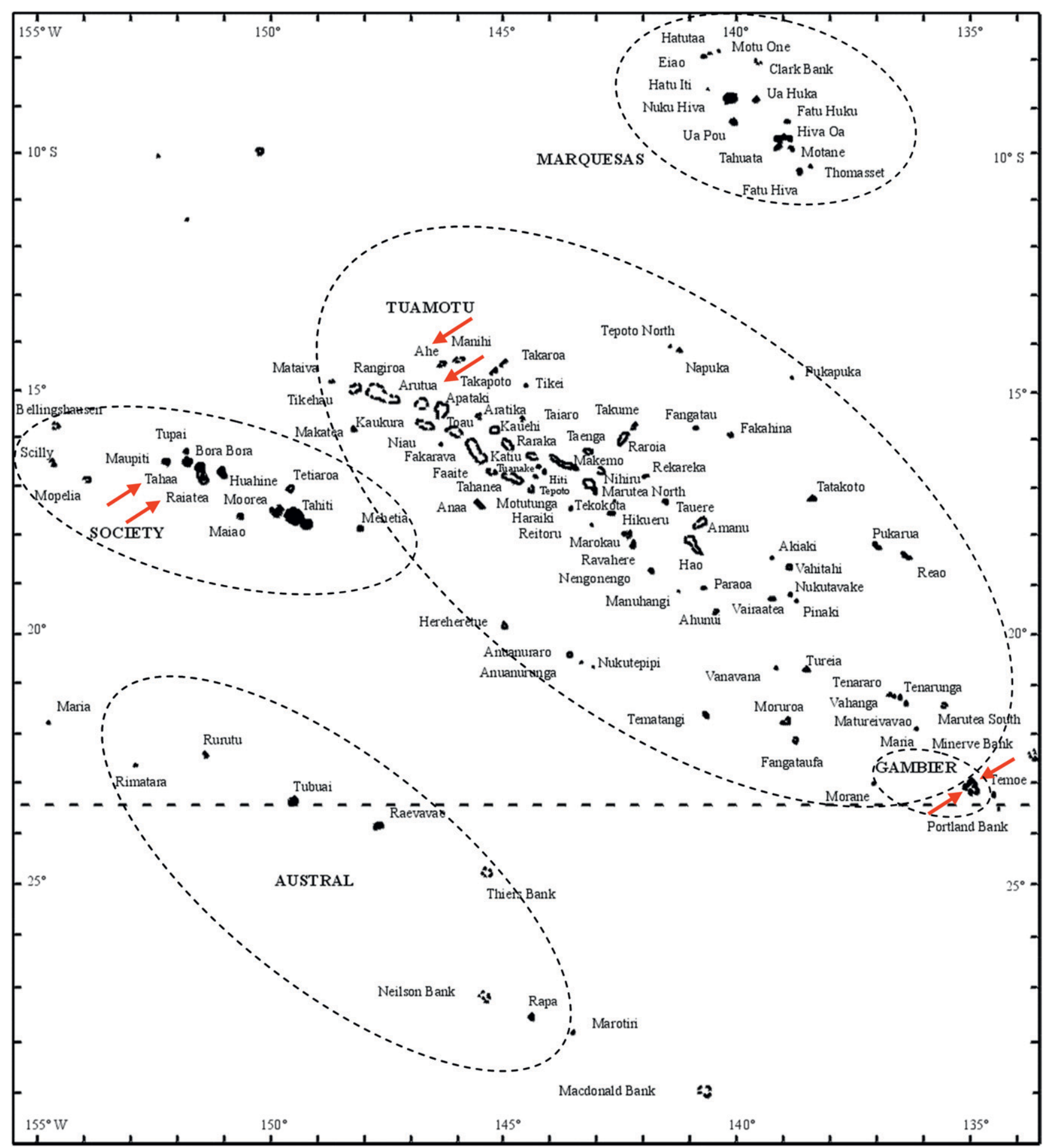

Figure 1. Map showing the locations of the French Polynesia archipelagos. Red arrows indicate the grow-out locations used in the experiment: bays of Atiaoa and Taku in Gambier archipelago, atolls of Ahe and Arutua in Tuamotu archipelago, and Raiatea and Tahaa Islands in Society archipelago.

Cultured pearl grade is made up of two components: surface defects and lustre. When pearls are graded, the appearance of their surface is evaluated. The degree of imperfection is rated by the number of defects, that is, whether the pearl has a smooth surface or one or more spots. For the grade classification, good pearl quality corresponds to $\mathrm{AB}, \mathrm{A}-\mathrm{C}$, and $\mathrm{C}$ grades, medium quality corresponds to $\mathrm{D}^{+}$and $\mathrm{D}$ grade, low quality to $\mathrm{D} 1$ and $\mathrm{D} 2$ grades, and $\mathrm{R}$ to rejects. In our study, the AB grade corresponded to A and B grades as described according to the official Tahitian classification (Tayale et al. 2012). The $\mathrm{C}$ grade concerned pearls with two or three spots. $\mathrm{D}^{+}$pearls showed light surface damage, with no white spots on the surface but dimples. D grade pearls had both a spotted surface and white spots. D1 and D2 grades corresponded to pearls with damaged surfaces, but D1 grade pearls also had lustre and color that was absent in D2. 


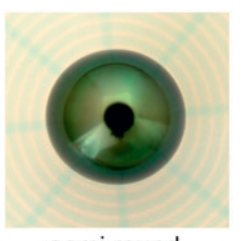

semi round SR

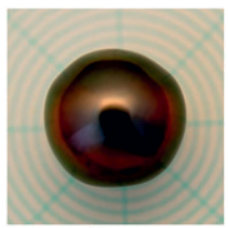

semi baroque short

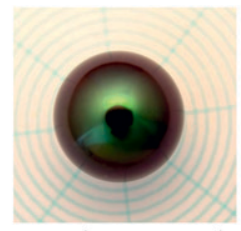

round near round RDNR

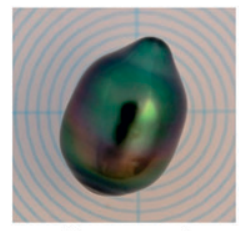

semi baroque long SBQL

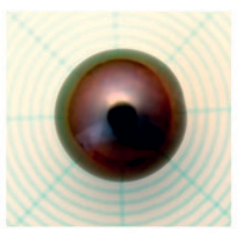

near semi round NSR

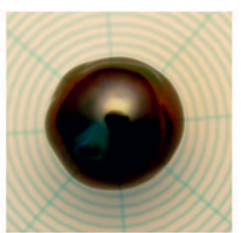

baroque short BQS

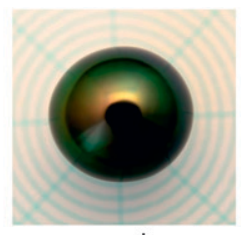

oval

OV

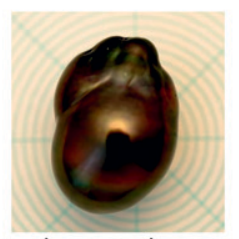

baroque long BQL

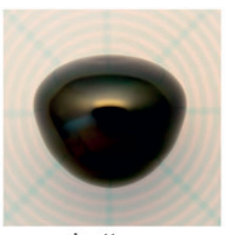

button

$\mathrm{BU}$

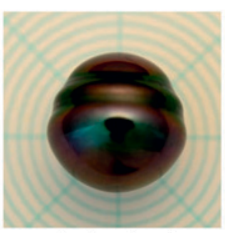

circle short CRS

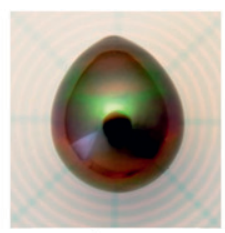

drop

DP

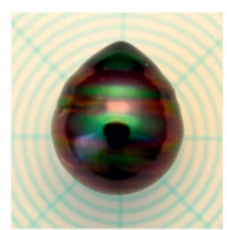

circle long CRL

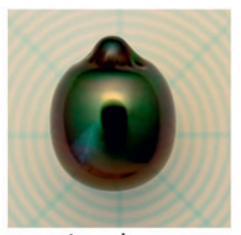

top drop

TD

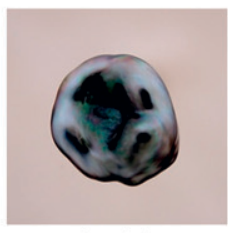

keshi K

Figure 2. Cultured Pinctada margaritifera pearl shape as classified by GIE Poe O Rikitea.

All quality traits were visually classified by the naked eye (no magnification devices, such as a jeweler loupe, were used).

Pearl size was assessed by nacre thickness and nacre weight. These two components were measured as described in Ky et al. (2013). Some keshi (K, small non nucleated pearls formed when an oyster rejects and expulses the implanted nucleus during the culture period) were harvested, but not graded.

\section{Statistical Analysis}

Univariate analysis was performed for each variable. Categorical variables (shape, grade, and color categories) were expressed as numbers and percentages. To compare results from the six grow-out locations, chi-square tests and Fisher's exact tests for count data were performed to check if there was a difference between distributions. If the overall test was significant, pairwise comparisons between all pairs of proportions were calculated to identify which groups differed (represented by letters in the tables and figures).

Statistical analysis was performed using $\mathrm{R}$ version 3.2.1 software ( $\mathrm{R}$ Foundation for Statistical Computing). The significance threshold was set at $P \leq 0.05$.

\section{RESULTS}

Among the 2,880 grafted oysters, the average retention rate was $86 \%(n=2476)$, with $12 \%(n=346)$ rejection and $2 \%(n=$ 58) mortality at 45 days postgrafting. After transfer to the five sites 3 months later postgraft, no mortality has been recorded due to transport. At harvest time, 2,236 pearls were collected for $78 \%$ of the total oysters grafted.

\section{Cultured Pearl Color Variation}

The average cultured pearl color proportions reveal that one quarter corresponded to a green or medium tone, and the other three quarters consisted of nearly equivalent proportions of dark and light tones (Table 1). Comparison among the growout locations first revealed that the proportion of medium color pearls was equivalent among all sites. Variation existed for the other color categories, with Raiatea and Tahaa Islands showing on average $31 \%$ more dark-toned pearls than the sites in the other archipelagos. In contrast, Ahe and Arutua atolls showed on average $28 \%$ more light-toned pearls in comparison with the other sites, except for Tahaa Island, which showed no significant difference. For the green color, Atiaoa and Taku bays showed significantly greater proportions, which were nearly twice those found in the other culture sites (Fig. 4). Consequently, at an archipelago scale, Gambier, Society, and Tuamotus were characterized by greater proportions of green pearls $(+56 \%)$, dark tone $(+31 \%)$, and light tone $(+28 \%)$, respectively.

\section{Cultured Pearl Shape Variation}

The most frequent cultured pearl shape was the circle category (nearly half of the harvested samples). The roundish shapes (a quarter of the harvest) ranked second, followed by baroque-like and other pearl shapes (Table 1 and Fig. 2). The breakdown of the identified shapes within each of the four main
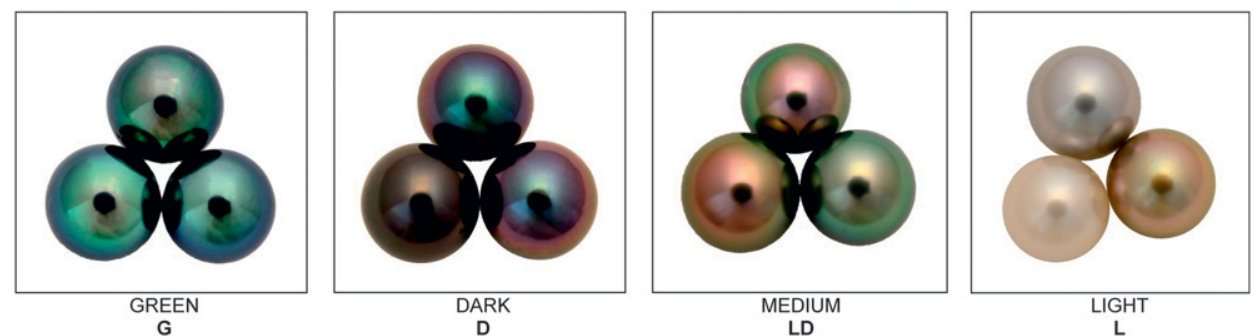

Figure 3. Cultured Pinctada margaritifera pearl color categories as classified by GIE Poe O Rikitea. 
TABLE 1.

Shape, grade, color, weight, and size of cultured pearls $(n=2236)$ from Pinctada margaritifera.

\begin{tabular}{llc}
\hline \hline & Cultured pearl traits & Rate $(\boldsymbol{N}) /$ mean \\
Shape & Roundish: RDNR - SR - NSR & $26.3(588)$ \\
& Baroque like: SBQS, SBQL, BQS, & $19.7(440)$ \\
BQL & \\
& Others: OV, BU, DP, TD & $7.8(175)$ \\
& Circles: CRS, CRL & $46.2(1,033)$ \\
Grade & AB & $0.3(6)$ \\
& A-C & $31.9(713)$ \\
& C & $2.1(46)$ \\
& D & $7.9(179)$ \\
& D & $39.9(862)$ \\
& D1 & $2.5(57)$ \\
& D2 & $13.5(302)$ \\
Color & R & $1.9(43)$ \\
& Dark & $38.8(867)$ \\
& Medium & $7.6(171)$ \\
& Light & $35.4(792)$ \\
Quantitative & Green & $18.2(406)$ \\
& Weight (g) & $1.15( \pm 0.38)$ \\
& Size (mm) & $8.51( \pm 1.13)$ \\
\hline
\end{tabular}

Data are expressed in percentages, with frequencies $(N)$, except for the quantitative traits, which are expressed in means \pm SD. Nomenclature corresponding to shape, grade, and color are described in Materials and Methods section.

categories is given in Table 2. Among the circle shapes, an equivalent ratio was found between short (CRS) and long (CRL) forms. The commercially valuable round pearl shape (RDNR) accounted for only $7 \%$ of the total harvest (Table 2).

Comparison among the grow-out locations first showed that baroque-like shapes were present in similar proportions in all sites (Fig. 5). By contrast, Atiaoa and Taku bays (Gambier archipelago) showed on average (1) the lowest rates of circled pearls ( $-38 \%$ compared with the other sites) and (2) the highest rates of roundish pearls $(+36 \%)$ and pearls of "other" shapes $(+16 \%)$ (Fig. 5). Consequently, at an inter-archipelago scale, the Gambier sites had a profile opposite to that found in Society and Tuamotu locations for these shapes.

\section{Cultured Pearl Grade Variation}

Cultured pearl grade was predominantly represented by medium quality ( $\mathrm{D}^{+}$and $\mathrm{D}$ grades), which accounted for nearly half of the harvested pearls. Good-quality pearls (AB, A-C, and C) represented $34.3 \%$ of the total harvest, whereas low-quality pearls (D1, D2, and R) represented only 17.9\% (Table 1). Comparison among grow-out locations revealed that Atiaoa Bay location produced the highest rate of good-quality grades $(+42 \%)$ compared with the average rate of Ahe and Tahaa $(28.7 \%)$, which were the lowest (Table 3). The three other locations (Taku Bay, Arutua, and Raiatea) showed intermediate values $(35.7 \%$ on average): $+24.4 \%$ higher than the mean rate of good-quality pearls in Ahe and Tahaa. Inversely, the Gambier locations had the lowest average rate of low-quality pearls compared with the mean values of the other sites $(-36 \%)$. For the medium-quality grade, no clear differences were observed (Table 3). Consequently, at an inter-archipelago scale, the Gambier sites produced the highest rate of goodquality pearls in comparison with Society and Tuamotu locations.

\section{Cultured Pearl Size Variation}

The average pearl weight and size among the 2,236 pearls harvested were $1.15 \mathrm{~g}$ and $8.51 \mathrm{~mm}$, respectively, after $20 \mathrm{mo}$ of culture (Table 1). Significant differences appeared between the grow-out sites, with Atiaoa and Taku bays showing the lowest pearl weight and size (Table 3). By contrast, Ahe and Arutua atolls showed the highest values, which were significantly $22 \%$ and $5 \%$ greater for pearl weight and size, respectively, than those found in the Gambier archipelago. Ahe showed the highest values for both pearl weight and size. Raiatea and Tahaa Islands had intermediate values. Consequently, at an inter-archipelago scale, the Tuamotu sites showed the highest values for pearl weight and size compared with Society and Gambier locations, where values were lower.

\section{DISCUSSION}

Experimental standardization is necessary to compare the effects of grow-out locations on the expression of cultured pearl quality traits. Factors contributing to pearl quality are commonly known to include the oyster species (genetic factors), the culture zone in which the recipient oyster is reared during pearl development (environmental factors), and the interactions of the organism with the environment (Snow et al. 2004). The large experimental graft in this study was designed to minimize variation caused by donor oyster influence, as previous studies (McGinty et al. 2010) have shown donors to play a primary role in determining color in Pinctada margaritifera. A hatcheryproduced family with yellow inner shell coloration was therefore used as a source of donor oysters. This phenotype has been shown to produce multicolor pearls with a large range of darkness levels, which made it more suitable for assessing the variation that could be produced due to grow-out environment than a donor family with the green inner shell phenotype of donors, which produces mainly dark green pearls (Ky et al. 2015 b). In addition, a single donor family was used for all grafts, as family effects have been demonstrated for pearl grade, shape, color, and size (Ky et al. 2013, 2015e). External factors such as grafter skill, grafting season, and culture method have been shown to affect pearl shape in P. margaritifera (Ky et al. 2015d, Kishore \& Southgate 2016). To remove these sources of variation, grafts were made by the same technician and growout was performed for the same culture duration in the same season, using the chaplets culture method.

Cultured pearl quality showed a clear archipelago signature in this study in terms of several of the criteria examined. For color expression, each archipelago has its specificity: a high proportion of green pearls in Gambier, light-colored pearls in Tuamotu, and dark-colored pearls in Society. As first shown by Ky et al. (2015a), the grow-out environment of the recipients plays a key role in the final pearl color achieved by harvest relative to the donor inner shell color phenotype used. Effects of temperature, salinity, turbidity, light, climate, and diet have been reported in some marine gastropods (Sokolova \& Berger 2000, Liu et al. 2009). Such environmental parameters are known to vary between the archipelagos of this study. For 


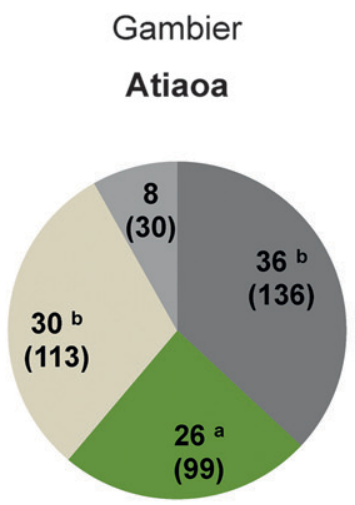

Taku

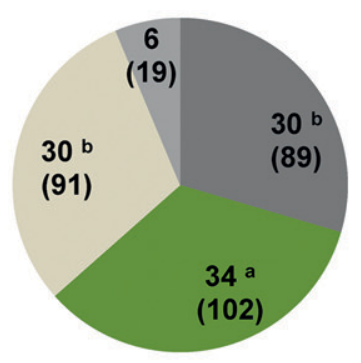

Tuamotu

Ahe

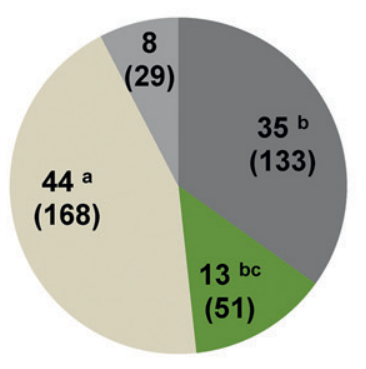

Arutua

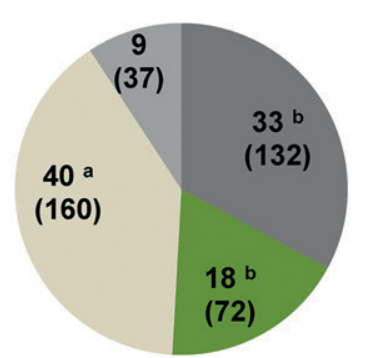

Society

Raiatea

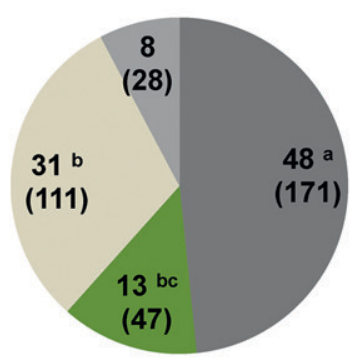

Tahaa

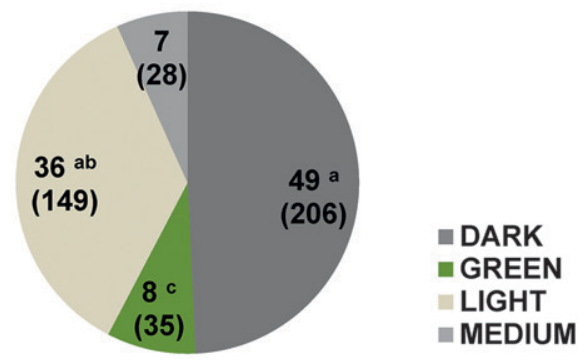

Figure 4. Cultured Pinctada margaritifera pearl color distribution among the grow-out sites. Data are expressed in percentage and frequencies (in brackets). The data points significantly different between the locations at $P<0.05$ are indicated with letters.

temperature, the Gambier archipelago is characterized by contrasting seasons, with a large range of temperature variation $\left(21.3-28.8^{\circ} \mathrm{C}\right.$ in 2012$)$ due to its southern latitude, in comparison with Society and North Tuamotu $\left(27.3-29.2^{\circ} \mathrm{C}\right.$ in 2012) (Blay et al. 2016, Le Pabic et al. 2016). Concerning turbidity and light, island lagoons (Gambier and Society archipelagos) are characterized by relatively high suspended particulate matter, supplied from nearby mountains and accentuated during rainy periods, whereas atoll lagoons (Tuamotu archipelago) have oligotrophic waters with low turbidity (Pouvreau \& Prasil 2001).

An archipelago specificity was also recorded for cultured pearl shape, with more pearls of the roundish classes found in Gambier and more circles in both Tuamotu and Society. The balance between roundish and circled pearls in these contrasting sites (Gambier versus Tuamotu and Society) could be explained by the physiological status of the grafted recipient oyster in relation to lagoon temperature. Season effect on circle pearl formation had already been demonstrated in Ky et al. (2014b). Significantly higher amounts of circled pearls were found in Tuamotu and Society, which could be related to gonad disturbance, because it is in the gonad that the pearl undergoes its formation. The relationship between gonad maturity, which will differ between archipelagos due to environmental differences, and the presence of the saibo nucleus, may affect circle formation, in detriment to roundish pearl shapes (Southgate \& Lucas 2008).

For overall cultured pearl grade, an archipelago signature appeared in favor of Gambier, where the highest rate of good quality pearls was found in comparison with Tuamotu and
Society. This was in accordance with the significantly higher proportion of green pearls harvested in Gambier $(+56 \%$ in comparison with other archipelagos) and evidence from previous studies demonstrating a positive correlation between this color and higher pearl grade (Ky et al. 2014b), including for animals of the same age (Ky et al. 2015f). Pearl grade is based on the evaluation of surface defects and lustre. Concerning pearl surface defects, Cuif et al. (2011) showed that the main

TABLE 2.

Detailed breakdown of shape in Pinctada margaritifera cultured pearls $(n=2236)$ as classified by GIE Poe O Rikitea (see Fig. 2).

\begin{tabular}{llc}
\hline \hline \multicolumn{1}{c}{ Cultured pearl shape } & & Rate $(\boldsymbol{N})$ \\
\hline Roundish & RDNR & $7.1(151)$ \\
& SR & $13.9(298)$ \\
\multirow{4}{*}{ Others } & NSR & $6.4(139)$ \\
& OV & $3.5(73)$ \\
& BU & $1.1(23)$ \\
\multirow{5}{*}{ Baroque like } & DP & $2.2(47)$ \\
& TD & $1.5(32)$ \\
& SBQS & $9.6(215)$ \\
Circled & SBQL & $7.5(168)$ \\
& BQS & $1.2(27)$ \\
& BQL & $1.3(30)$ \\
& CRS & $21.3(492)$ \\
& CRL & $23.4(541)$ \\
\hline
\end{tabular}

Data are expressed in percentages followed by frequencies $(N)$. 


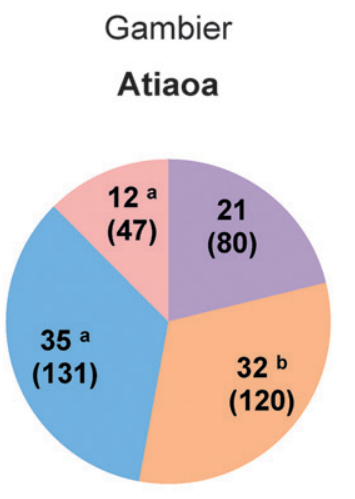

Taku

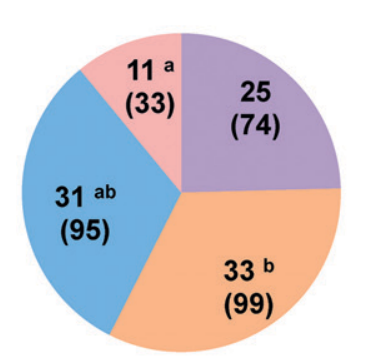

Tuamotu

Ahe

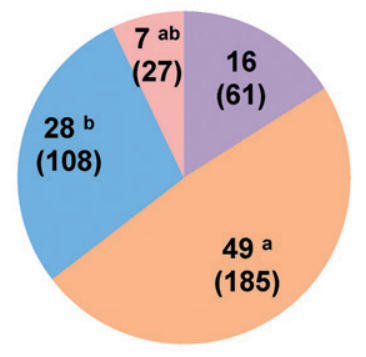

Arutua

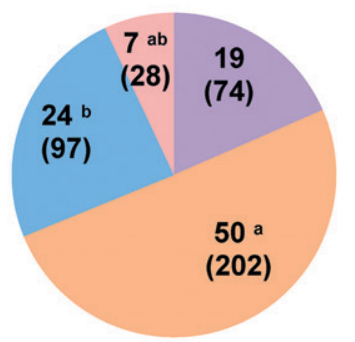

Society

Raiatea

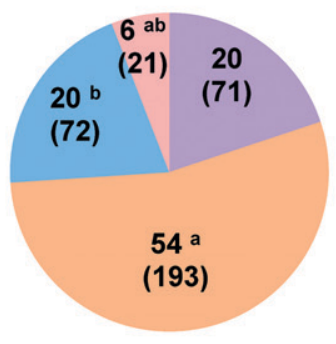

Tahaa

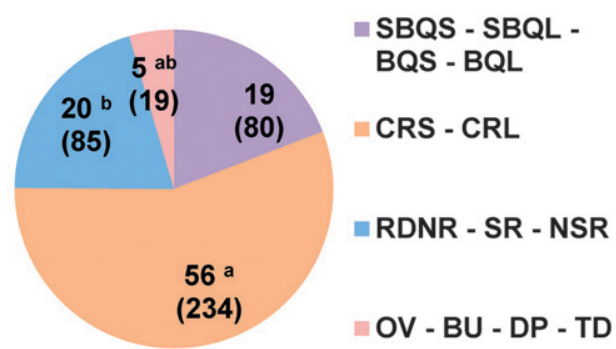

Figure 5. Cultured Pinctada margaritifera pearl shapes distribution among the grow-out sites. Data are expressed in percentage and frequencies (in brackets). The data points significantly different between the locations at $P<0.05$ are indicated with letters.

cause of irregularities that could be found in future-harvested pearls appeared to be the first nacreous materials deposited on the nucleus surface. If this initial matrix is not well established, the harvested pearls will have a much greater number of surface defects. High temperature and its associated environmental factors such as low levels of dissolved oxygen, lowered salinity due to summer rainfall, and toxic blooms of algae and bacteria (Southgate \& Lucas 2008) could all contribute to explaining archipelago specificity. The lustre of pearls is thought to be influenced by nacre deposition rate a few weeks prior to harvest

TABLE 3.

Grade and quantitative traits (weight and size) of Pinctada margaritifera-cultured pearls $(n=2236)$ from six grow-out locations.

\begin{tabular}{|c|c|c|c|c|c|c|c|c|}
\hline & & \multicolumn{6}{|c|}{ Geographic grow-out location } & \multirow[b]{3}{*}{ Significance } \\
\hline & & \multicolumn{2}{|c|}{ Gambier } & \multicolumn{2}{|c|}{ Tuamotu } & \multicolumn{2}{|c|}{ Society } & \\
\hline \multicolumn{2}{|c|}{ Cultured pearl traits } & Atiaoa & Taku & Ahe & Arutua & Raiatea & Tahaa & \\
\hline \multirow[t]{11}{*}{ Grade } & Good & $40.7^{\mathrm{a}}(154)$ & $37.5^{\mathrm{b}}(116)$ & $29.1^{\mathrm{c}}(111)$ & $35.4^{\mathrm{b}}(144)$ & $34.2^{\mathrm{b}}(122)$ & $28.3^{\mathrm{c}}(118)$ & $*$ \\
\hline & $\mathrm{A}-\mathrm{C}$ & $35.7^{\mathrm{a}}(135)$ & $34.5^{\mathrm{ab}}(104)$ & $27.8^{\mathrm{b}}(106)$ & $34.9^{\mathrm{a}}(140)$ & $31.9^{\mathrm{b}}(114)$ & $27.3^{\mathrm{b}}(114)$ & $*$ \\
\hline & $\mathrm{C}$ & $5.0(19)$ & $3.0(9)$ & $1.3(5)$ & $0.5(2)$ & $2.0(7)$ & $1.0(4)$ & - \\
\hline & $\mathrm{AB}$ & $0.0(0)$ & $1.0(3)$ & $0.0(0)$ & $0.5(2)$ & $0.3(1)$ & $0.0(0)$ & - \\
\hline & Medium & $47.1^{\mathrm{ab}}(178)$ & $43.1^{\mathrm{b}}(130)$ & $48.8^{\mathrm{a}}(176)$ & $46.8^{\mathrm{ab}}(188)$ & $47.6^{\mathrm{ab}}(170)$ & $51.7^{\mathrm{a}}(216)$ & $*$ \\
\hline & $\mathrm{D}^{+}$ & $11.9^{\mathrm{a}}(45)$ & $6.6^{\mathrm{b}}(20)$ & $8.9^{\mathrm{ab}}(34)$ & $6.7^{\mathrm{b}}(27)$ & $7.8^{\mathrm{ab}}(28)$ & $5.3^{\mathrm{b}}(22)$ & $* *$ \\
\hline & $\mathrm{D}$ & $35.2^{\mathrm{b}}(133)$ & $36.5^{\mathrm{b}}(110)$ & $39.9^{\mathrm{ab}}(152)$ & $40.1^{\mathrm{ab}}(161)$ & $39.8^{\mathrm{ab}}(142)$ & $46.4^{\mathrm{a}}(194)$ & $*$ \\
\hline & Low & $10.0^{\mathrm{b}}(38)$ & $13.0^{\mathrm{b}}(39)$ & $20.7^{\mathrm{a}}(79)$ & $15.4^{\mathrm{ab}}(62)$ & $16.0^{\mathrm{ab}}(57)$ & $20.1^{\mathrm{a}}(84)$ & $* * *$ \\
\hline & D1 & $1.8(7)$ & $2.7(8)$ & $3.9(15)$ & $2.7(11)$ & $2.5(9)$ & $1.7(7)$ & NS \\
\hline & D2 & $8.2^{\mathrm{b}}(31)$ & $10.3^{\mathrm{b}}(31)$ & $16.8^{\mathrm{a}}(64)$ & $12.7^{\mathrm{ab}}(51)$ & $13.4^{\mathrm{ab}}(48)$ & $18.4^{\mathrm{a}}(77)$ & $* * *$ \\
\hline & $\mathrm{R}$ & $2.1(8)$ & $5.3(16)$ & $1.3(5)$ & $1.7(7)$ & $2.0(7)$ & $0.0(0)$ & - \\
\hline \multirow[t]{2}{*}{ Quantitative } & Weight (g) & $1.06^{\mathrm{c}}( \pm 0.35)$ & $1.02^{\mathrm{c}}( \pm 0.32)$ & $1.28^{\mathrm{a}}( \pm 0.44)$ & $1.26^{\mathrm{a}}( \pm 0.40)$ & $1.14^{\mathrm{b}}( \pm 0.39)$ & $1.13^{\mathrm{b}}( \pm 0.33)$ & $* * *$ \\
\hline & Size (mm) & $8.35^{\mathrm{c}}( \pm 0.98)$ & $8.21^{\mathrm{c}}( \pm 0.88)$ & $8.90^{\mathrm{a}}( \pm 1.57)$ & $8.58^{\mathrm{b}}( \pm 1.00)$ & $8.45^{\mathrm{b}}( \pm 0.99)$ & $8.56^{\mathrm{b}}( \pm 0.92)$ & $* * *$ \\
\hline
\end{tabular}

Data are expressed in percentages, with frequencies $(N)$, except for the quantitative traits, which are expressed by means \pm SD.Grade nomenclature is described in Materials and Methods section. The traits significantly different between the five locations at $0.01<P \leq 0.05,0.001<P \leq 0.01$, and $P \leq 0.001$ are indicated with 1,2 , or 3 asterisk(s) $(*)$, respectively, and NS for not significant. The data points significantly different between the locations at $P<0.05$ are indicated with letters. 
time. Pearl farmers restrict pearl harvesting to winter as much as possible because nacre deposition is at its slowest in this period; especially in Gambier archipelago, where the seasonal difference are marked (Blay et al. 2013). This practice is believed to produce pearls with maximum lustre. Conversely, pearl harvest during the summer season, where nacre deposition rate is at its highest in this period, is believed to produce pearls with a lack of lustre. Lack of lustre is often observed in the north of Tuamotu archipelago, where water temperature variation is lower than in Gambier. Snow et al. (2004) hypothesized that pearls with a brilliant lustre are produced by consistent and regular crystal formation in winter season.

For cultured pearl size, northern Tuamotu locations showed the highest value in terms of both weight and diameter of pearls, in comparison with Gambier and to a lesser extent Society. This result was in accordance with previous studies showing that cultured pearl size and the biometric parameters related to recipient oyster shell growth were highest for warmer sites with low seasonal temperature variation in comparison with the southern latitude sites (Le Pabic et al. 2016). Nacre thickness and weight are directly correlated with the nacre biomineralization process, as the epithelial cells from the outer surface of the mantle tissue (which lines the inner surface of the shell) have the property of synthesizing different calcium carbonate polymorphs (Wilbur 1964,Watabe 1988). The nacre is formed by hundreds of thousands of aragonite crystal and protein matrix, which overlap alternately on the nucleus, as observed by electron microscopy (Zhang \& Xu 2013). This biomineralization process is known to be affected by both temperature and salinity (Kvingedal et al. 2008). Joubert et al. (2014) showed that shell growth is influenced by both microalgal concentration and temperature and that these environmental factors regulate the expression of most of the protein matrix genes. Olson et al. (2012) found a strong correlation between Pinctada margaritifera shell nacre ultrastructure and environmental temperature and pressure. Society archipelago is characterized by a significant rainy period (during most of the summer season) that does not occur in Tuamotu archipelago. Thus, seasonal variation in salinity may be more accentuated in Society than Tuamotu. These rainy periods in Society may also drain some minerals and other nutrients or pollutants from the mountains, which did not occur in the atoll of Tuamotu as there are no mountains there. Such differences would also have an impact on food availability and the nutritional value of the specific microalgae populations that grow in each of the contrasting grow-out locations.

\section{CONCLUSIONS}

In French Polynesia, pearl farms are distributed over a vast area covering a surface as large as Europe. The contrasting latitude and the distinct and specific environments of these culture sites (i.e., water temperature, salinity, nutrient levels) mean that the archipelagos could influence the expression of commercial pearl quality traits. This study recorded variation in pearl color, shape, grade, and size issued from the same donor phenotype and recipient pearl oyster group reared in different culture sites in different archipelagos, but without the actual measurement of environmental parameters. On a broader scale, irrespective of donor phenotype, the archipelago quality trait signatures are also observed in the overall production diversity, as seen at the Tahitian pearl auction exhibition, where these patterns of commercial quality trait signatures have already been observed. This raises questions about the feasibility of achieving homogeneity of pearl quality through the diffusion of homogeneous selected hatchery-produced donor oyster lines from a genetic improvement program, when handling such complex phenotypes (as opposed to a "simple" phenotype with Mendelian inheritance as described in Ky et al. 2016). In the light of these archipelago-scale quality signatures, different strategies and targeted commercial pearl quality trait selection should be set up to take advantage of the contrasting environments, together with the diffusion of specific pearl oyster phenotypes. In the Gambier archipelago, pearl size should be targeted. By contrast, in Tuamotu, the priority should be darker pearls, to respond to international market demand. In Society, both size and wider range of colorful pearls must be targeted. Multiple oyster lines will be produced in the future to enable an appropriate choice of donors for the production sites to enhance Tahitian pearl quality.

\section{ACKNOWLEDGMENTS}

We would especially like to thank the different pearl farms that contributed to this study: the host site and employees of Regahiga Pearl Farm (Mangareva Island, Gambier archipelago) for their generous support, as well as the five other host sites for the pearl oyster culture maintenance: Pommier Pearl Farm, Ahe Royal Pearl (Arutua and Ahe atolls, respectively, Tuamotu archipelago), Love Here Pearl Farm and Perle d'O Pearl Farm (Tahaa and Raiatea Islands, Society archipelago), and Pakaiti pearl farm (Mangareva Island, Gambier archipelago).

\section{LITERATURE CITED}

Blay, C., S. Parrad, P. Cabral, V. Aiho \& C. L. Ky. 2016 Correlations between cultured pearl size parameters and PIF177 biomarkers expression in Pinctada margaritifera families reared in two contrasting environments. Estuar. Coast. Shelf Sci. doi:10.1016/j.ecss.2016.05.020.

Blay, C., M. Sham-Koua, V. Vonau, R. Tetumu, P. Cabral \& C. L. Ky. 2013. Influence of nacre deposition on rate on cultured pearl grade and colour in the black-lipped pearl oyster Pinctada margaritifera using farmed donor families. Aquacult. Int. 22:937-953.

Cuif, J. P., Y. Dauphin, L. Howard, J. Nouet, S. Rouzière \& M. Salomé. 2011. Is the pearl layer a reversed shell? A re-examination of the theory of pearl formation through physical characterizations of pearl and shell development stages in Pinctada margaritifera. Aquat. Living Resour. 23:277-284.

Ellis, S. \& M. Haws. 1999. Producing pearls using the black-lip pearl oyster (Pinctada margaritifera). Center for Tropical and Subtropical Aquaculture Publication 141:1-8.

Gervis, M. H. \& N. A. Sims. 1992. The biology and culture of pearl oysters (Bivalvia pteriidae). London, UK: International Centre for Living Aquatic Ressources Management (ICLARM). Stud. Rev. 21. $49 \mathrm{pp}$

Jerry, D. R., R. Kvingedal, C. E. Lind, B. S. Evans, J. U. Taylor \& A. E. Safari. 2012. Donor oyster derived heritability estimates and the effect of genotype $\mathrm{x}$ environment interaction on the production of 
pearl quality traits in the silver-lip pearl oyster, Pinctada maxima. Aquaculture 338:66-71.

Joubert, C., C. Linard, G. Le Moullac, C. Soyez, D. Saulnier, V. Teaniniuraitemoana, C. L. Ky \& Y. Gueguen. 2014. Temperature and food influence shell growth and mantle gene expression of shell matrix proteins in the pearl oyster Pinctada margaritifera. PLoS One 9:e103944.

Karampelas, S., E. Fritsch, J.-P. Gauthier \& T. Hainschwang. 2011. UV-Vis-NIR reflectance spectroscopy of natural-color saltwater cultured pearls from Pinctada margaritifera. Gems \& Gemol 47:3137.

Kishore, P. \& P. C. Southgate. 2016. The effect of different culture methods on the quality of round pearls produced by the black-lip pearl oyster Pinctada margaritifera (Linnaeus, 1758). Aquaculture 451:65-71.

Kvingedal, R., B. S. Evans, J. U. Taylor, J. Knauer \& D. R. Jerry. 2008. Family by environment interactions in shell size of 43-day old silverlip pearl oyster (Pinctada maxima), five families reared under different nursery conditions. Aquaculture 279:23-28.

Ky, C. L., C. Blay, V. Aiho, P. Cabral, G. Le Moullac \& C. Lo. $2015 \mathrm{a}$. Macro-geographical differences influenced by family-based expression on cultured pearl grade, shape and colour in the black-lip pearl oyster Pinctada margaritifera: a preliminary case study in French Polynesia. Aqua Research. doi:10.1111/are.12880.

Ky, C. L., C. Blay \& C. Lo. 2015e. Half-sib families effect on cultured pearl quality traits in the black-lipped pearl oysters Pinctada margaritifera: testing for indirect benefits of polyandry and polygyny. Aqua Inter 24:171-182.

Ky, C. L., C. Blay, M. Sham Koua, C. Lo \& P. Cabral. 2014b. Indirect improvement of pearl grade and shape in farmed Pinctada margaritifera by donor "oyster" selection for green pearls. Aquaculture 432:154-162.

Ky, C. L., C. Blay, M. Sham Koua, V. Vanaa, C. Lo \& P. Cabral. 2013. Family effect on cultured pearl quality in black-lipped pearl oyster Pinctada margaritifera and insights for genetic improvement. Aquatic Liv Res 26:133-145.

Ky, C. L., J. Demmer, C. Blay \& C. Lo. 2015f. Age-dependence of cultured pearl grade and colour in the black-lipped pearl oyster Pinctada margaritifera. Aqua Research. doi:10.1111/are.12938.

Ky, C. L., C. Lau, M. Sham Koua \& C. Lo. 2015c. Growth performance comparison of Pinctada margaritifera juveniles produced by thermal shock or gonad scarification spawning procedures. J. Shellfish Res. 34:811-817

Ky, C. L., L. Le Pabic, M. Sham Koua, N. Molinari, S. Nakasai \& D. Devaux. 2015b. Is pearl colour produced from Pinctada margaritifera predictable through shell phenotypes and rearing environments selections? Aqua Research. doi:10.1111/are/12947.

Ky, C. L., N. Molinari, E. Moe \& S. Pommier. 2014a. Impact of season and grafter skill on nucleus retention and pearl oyster mortality rate in Pinctada margaritifera aquaculture. Aqua Inter 22:1689-1701.

Ky, C. L., S. Nakasai, N. Molinari \& D. Devaux. 2015d. Influence of grafter skill and season on cultured pearl shape, circles and rejects in Pinctada margaritifera aquaculture in Mangareva lagoon. Aquaculture 435:361-370.

Ky, C. L., S. Nakasai, S. Pommier, M. Sham Koua \& D. Devaux. 2016. The Mendelian inheritance of rare flesh and shell colour variants in the blacklipped pearl oyster (Pinctada margaritifera). Anim. Genet. (in press).
Le Pabic, L., P. Parrad, M. Sham Koua, S. Nakasai, D. Saulnier, D. Devaux \& C. L. Ky. 2016. Culture site dependence on pearl size realization in Pinctada margaritifera in relation to recipient oyster growth and mantle graft biomineralization gene expression using the same donor phenotype. Estuar. Coast. Shelf Sci. doi:10.1016/j.ecss.2016.03.009.

Le Pennec, M. \& D. Buestel. 2010. Mythe et histoire de la nacre et de la perle. In: Le Pennec, editor. Faaa, French Polynesia : HQ Imaging. Huîtreperlière et perle de Tahiti.

Liu, X., F. Wu, H. Zhao, G. Zhang \& X. Guo. 2009. A novel shell color variant of the pacific abalone Haliotis discus hannai into subject to genetic control and dietary influence. J. Shellfish Res. $28: 419-424$

Matlins, A. L. 1996. The pearl book: the definitive buying guide. Woodstock, VT: Gemstone Press. 198 pp.

McGinty, E. L., B. S. Evans, J. U. U. Taylor \& D. R. Jerry. 2010. Xenografts and pearl production in two pearl oyster species, $P$. maxima and $P$. margaritifera: effect on pearl quality and a key to understanding genetic contribution. Aquaculture 302:175-181.

Olson, I. C., R. Kozdon, J. W. Valley \& P. U. Gilbert. 2012. Mollusk shell nacre ultrastructure correlates with environmental temperature and pressure. J. Am. Chem. Soc. 134:7351-7358.

Pouvreau, S. \& V. Prasil. 2001. Growth of the black-lip pearl oyster, Pinctada margaritifera, at nine sites of French Polynesia: synthesis of several sampling designs conducted between 1994 and 1999. Aquat. Living Resour. 14:155-163.

Snow, M., A. Pring, P. Self, D. Losic \& J. Shapter. 2004. The origin of the colour of pearls in iridescence from nano-composite structures of the nacre. Am. Mineral. 89:1353-1358.

Sokolova, I. \& V. Berger. 2000. Physiological variation related to shell colour polymorphism in white sea Littorina saxatilis. J. Exp. Mar. Biol. Ecol. 245:1-23.

Southgate, P. C. \& J. S. Lucas. 2008. The pearl oyster. Oxford, UK: Elsevier. 575 pp.

Strack, E. 2006. Pearls. Germany: Rühle-Diebener-Verlag GmbH \& Co. KG. 706 pp.

Talvard, C. 2015. Bilan, la perle en 2013. In: Challier, S., editor. Points Forts de la PolynésieFrançaise. Papeete, Polynésie Française: Institut de la Statistique en PolynésieFrançaise. pp. 1-5.

Tayale, A., Y. Gueguen, C. Treguier, J. Le Grand, N. CochennecLaureau, C. Montagnani \& C. L. Ky. 2012. Evidence of donor effect on cultured pearl quality from a duplicated grafting experiment on Pinctada margaritifera using wild donors. Aquat. Liv. Res. 25:269280.

Taylor, J. \& E. Strack. 2008. The pearl oyster: biology and culture (pearl production). The Netherlands: Elsevier. pp. 273-302.

Wada, K. T. \& D. R. Jerry. 2008. Population genetics and stock improvement. In: Southgate, P. C. \& J. Lucas, editors. The pearl oyster. Oxford, UK: Elsevier. pp. 437-471.

Watabe, N. 1988. Shell structure. In: Trueman, C. M., editor. The mollusca, 11. Form and function. San Diego, CA: Academic Press. pp. 69-104.

Wilbur, K. 1964. Shell formation and regeneration. In: Saleuddin, A. \& K. Wilbur, editors. Physiology of mollusca. New York, NY: Academic Press. pp. 243-287.

Zhang, G. \& J. Xu. 2013. From colloidal nanoparticles to a single crystal: new insghts into the formation of nacre aragonite tablets. $J$. Struct. Biol. 182:36-43. 